\title{
Donald Trump's Alternative Facts Re-shaping National and International Discourses: The Big D. Analysis
}

\author{
Adebukunola Agnes Atolagbe, MBA(HRM), Ph.D(Engl) \\ Associate Professor of English \\ Department of English, Faculty of Arts \\ Lagos State University, Lagos, Nigeria.
}

\begin{abstract}
The author aims to interprete saying and doing in terms of identity, by examining the Inaugural Speech of President Donald Trump of the United States of America, and relate the use of language by political leaders, albeit all leaders, to the immediate and wider contexts of their speeches. This is particularly relevant in a globalised world, where the power of language and its use can have far reaching effects, and issues thrown up resonating with different categories of people, as with the particular discourse in focus. James Paul Gee's concept of the 'Big D' in Discourse Analysis (D/discourse Analysis) is employed in this qualitative study.
\end{abstract}

Key words: Donald Trump, D/discourse Analysis, Alternative Facts, Identity.

\section{INTRODUCTION}

Discourse Analysis is a branch of Linguistics that has tentacles in Sociology, Anthropology, Philosophy of meaning, Behavioural sciences and other fields of study that are interested in language, culture and society. Human beings engage in different kinds of communication, discourse, speech or talk, for different purposes; spoken words have a lot to do with the smooth running or otherwise of societies, institutions and relationships. How language content and structure are used to achieve the business of communication is the primary function of language studies (whether in the teaching or learning of the language).

English language is unarguably a world language that is probably the most used, desired, acquired or learned language in the world today (as second language - L2, foreign language LF, or special language - ESP). Moreover, due to globalization and its effects digitally or electronically, the world has become a small village in which the goings-on in any part of the world are easily captured in any other part of the world, irrespective of the language(s) involved. This is particularly true where the Western world or the world powers are concerned. 'Breaking News' in America, Britain, Russia, Germany, France or China for example, as relayed by $\mathrm{BBC}$ or CNN or Aljazeera, is heard and transmitted from mouth to mouth in different countries almost immediately. International Politics, policies, economies and relations may become unruffled thereafter; different countries may begin to align or re-align themselves towards concerted efforts in support of or against favourable or unfavourable "breaking news".

It is against this background that we find it academically insightful to consider the Inaugural speech of President Donald Trump of America, on 20 $0^{\text {th }}$ January, 2017, especially in relation to his "alternative facts" and how these resonate across the world, in a D/discourse analysis. 


\begin{abstract}
AIM
The analysis in this presentation is aimed primarily at interrogating the selected Inaugural speech to discover how it has shaped and continues to re-shape national and international discourses. Two basic objectives assist in achieving this aim, namely:

(i) A discussion of the semantic and pragmatic contents of the speech, (in the linguistic parlance) and

(ii) A discussion of the cognitive and social contexts of the speech.
\end{abstract}

Both discussions are hinged on the concept of "Identity" of the speaker and his people - Donald Trump the American, and the American people.

\title{
METHODOLOGY
}

This is a qualitative research but multidisciplinary. When America sneezes, it is as if the entire world catches cold, so the maiden Inaugural speech of the recently (newly) elected American President was purposively selected for analysis. The audio version on You-tube was recorded and the print form was also downloaded and printed out for analysis. Other previous campaign speeches which gave impetus to the content of the inaugural speech were also recorded or printed out for comparison or in-depth analysis.

The appropriate and relevant theory of Discourse analysis selected and explained under section 4.0 "literature" below, was applied in the analysis and discussion. The findings and implications are thereafter presented and conclusions arrived at.

\section{LITERATURE: DISCOURSE ANALYSIS, POLITICAL LANGUAGE AND IDENTITY.}

In this section, concepts that are most germane to this discourse are discussed.

\section{Discourse and Discourse Analysis}

In this section and subsequent ones, we discuss relevant literature on Discourse, Discourse Analysis, political language and identity. Discourse is language above the sentence or above the clause (Stubbs 1983:1), the next level in a hierarchy of morphemes, clauses and sentences (Harris 1951), "more than just language use, whether speech or writing, seen as a type of social practice (Fairclough 1992:28). Discourse names a part of language that has an intimate relation to syntax; it is the sequence of sentences - the ways in which sentences connect and relate to each other across time in speech or writing (Gee 2014:17,18). Discourse is languagein-use (language actually used in specific context)...concerned with the relationship between language and context, with the ways in which contexts help determine the full extent of what we mean or can be taken to have meant (Gee 2014:20). Discourse can best be thought of as "utterances", utterances as units of language production (whether spoken or written) that are inherently contextualized (Schiffrin 1994:41).

Thus, Discourse constitutes the social, with three dimensions of the social being knowledge, social relations and social identity - the three corresponding respectively to the three major functions of language (Ideational, Interpersonal and textual, Halliday,1997)...Discourse is shaped by power and invested with ideologies (Fairclough 1992:08). The study of discourse is therefore the study of any aspect of language use (Fasold 1990:65), and so it can not be restricted to the description of linguistic forms independent of the purpose or functions which those forms are designed to serve in human affairs (Brown and Yule 1983:1). 
In summary, Discourse can be studied from different perspectives, with different theories or approaches but all of these can be subsumed under the formalist approach or the functionalist approach. The latter, functionalist involves descriptive discourse analysis (studying it as language-in-use) and critical discourse analysis. While descriptive discourse analysis describes how language works in order to understand it or offer deeper explanations, critical discourse analysis goes further to speak to, and perhaps intervene in institutional, social or political issues, problems and controversies in the world. (Gee, 2014:9). Ayoola (2013) specifies these dimensions of Critical Discourse Analysis (CDA), relating them to Gumperz' (1982) position that language is socially situated identity, and to Fairclough's (1989) position that ideologies are closely linked to power and language use is a demonstration of power.

The analysis in this presentation hinges primarily on insights from Speech Acts Theory (Austin, 1969, Searle 1969, 1972), Gricean Pragmatics (1975) and Gee's concept of the Big DD/Discourse Analysis. As Gee (2014:20-22) posits, some linguists use the term "discourse analysis" for the study both of the connections among and across sentences as they follow after the other and the study of language-in-use in specific contexts while other linguists use the term to refer to just the first meaning, and they use the term "pragmatics" for the second - the study of language in context. Gee (op. cit.) argues further that when we speak or write, we simultaneously say something, do something, and are something. Different approaches foreground saying something (information), doing something (action) or being (identity). We say or do things as particular kinds of people. We interprete saying and doing in terms of identities, as different kinds of people or roles in society. (Gee 2014:20/21).

When two (or more) people are engaged in discourse - language interaction in context, they are communicating with each other via enacting and recognizing socially significant entities. The "Big 'D' Discourse", called D/discourse theory is about seeing interactive communication through the lens of socially meaningful identities. Speakers /writers use language, bodies, things (context) and "other stuff" that is not language in the world to enact socially significant identities (Gee 2014:25, 45). For example, to be recognized as a street gang member of some sort, one has to speak, act, dress, engage in ways of thinking/ believing/interacting, etc in the "right way" that are characteristics of such gang members. The concept of social identity as expounded in D/discourse analysis as explained thus far is thus preferred to Mey's (2006) Pragmatic Acts Theory even though the latter (Mey, 2000, 2006) may provide a theoretical route for the analysis, of situation-derived language acts through its 'Pragmeme', 'pract' or 'ipras' (Sokari and Ugwu, 2013:89) and even though Mey's theory was an attempt to "account for the indeterminate and situation-dependent nature of actual language use" which the Speech Acts Theory does not account for (because of its cognitively-oriented view of context) (Sokari and Ugwu 2013:88).

\section{Political Language}

Politics, like all spheres of social activity has its own code, that is, a language variety particular to a specific group (Beard 2000). Hahn (1981:111ff.) does not only take it for granted that there is what is called political language, but goes on to discuss 'rhetorical devices such as euphemisms, simplifications and generalizations which politicians rely upon in their art of saying nothing. Chilton and Schaffner (1997:212) on their part, argue that the multiplicity of acts that are performed through language (that is discourse) can be interpreted as serving many different purposes, not only political, but also heuristic, lucid, informative, etc. These diverse functions of discourse texts, which could be linked to political power, Chilton and Schaffner (op. cit.) call strategic functions which include - Coercion; Resistance, Opposition, Protest; Dissimulation, Legitimization and Delegitimization (Atolagbe 2010:26-27). 
Adetunji (2009) discusses the speech acts and rhetoric in Presidential Inaugural addresses of Nigeria's former President Olusegun Obasanjo and America's former President - George W. Bush; his work shows that even when speeches are functionally similar, the contexts in which they are created may reveal different sociopolitical realities and induce different inferences. In the same vein, Atolagbe (2010) reveals that the speech act in the speeches of former President Olusegun Obasanjo (of Nigeria) as a military Head of State and as a civilian Head of State are markedly different.

\section{Identity}

In Psychology, Sociology, Anthropology and Philosophy, Identity is the conception, qualities, beliefs and expressions that make a person (self-identity) or group (particular social category or social group). While 'identity' is a label, 'identification' refers to the classifying act itself. While identity is thus relational and contextual, identification is processional (involves creative or destructive processes) (Wikipedia). However, the formation of one's identity occurs through one's identification with significant others (e.g. parents, friends and other 'groups'). Psychologists often use the term identity to refer to personal identity while sociologists often use the term to refer to social identity or the collection of group membership that define the individual. We shall not delve into Weinreich's Identity Structure Analysis (ISA) here, but leave that to behavioural scientists.

While we recognize the need (like Psychologists) to investigate the question of how the personal self relates to the social environment, we rather focus more on social or cultural identity in this discourse - the collection of social roles that a person might play, why an individual tends to favour those they consider a part of their "in-group" over those they consider to be outsiders. Thus, crafting cognitive distinction between in- and out-groups can lead to subtle effects on people's evaluations of others as we find in the discourse text analysed in this presentation.

\section{DONALD TRUMP'S INAUGURAL SPEECH}

Prior to the assumption of Donald Trump as President of the United States of America on January $20^{\text {th }}, 2017$ when he took his oath of office, he had engaged in a series of campaign cum political speeches, traversing the length and breadth of America. Many listeners to those speeches, be they American nationals or otherwise, especially the media and the press (e.g. CNN, BBC, Aljazeera commentators), had felt that his speeches were divisive, racist, gender biased, arrogant or conservative in belief and position vis-à-vis the Democratic /Republican political divide. Therefore, all over the world, people were apprehensive of what would make up the President's Inaugural Speech.

Defining 'politics' and 'political discourse', and taking a definite stand, Adegbite (2009:11-12) states that both terms are ambiguous but he asserts that analysts of political discourse must make clear their motivations and perspectives since "it is difficult to imagine a fully objective and non-political account of political discourse." The aim and objectives of this essay have clearly stated our motivations and it is in this regard that we proceed to discuss the President's speech.

\section{Semantic Content}

'Semantics' refers to 'meaning', meaning as concept or meaning as referent. Thus we can discuss meaning conceptually or referentially. Semantics deals with 'what does X mean?' Meaning relations at (1) Word level e.g. synonyms, antonyms, polysemous words, 
homophones, meaning by extension or intension metaphors, lexicalizations, etc), (2) Sentence level (e.g. presupposition, paraphrase, entailment, contradiction, structural ambiguity, thematic role assignment, etc.) and (3) Utterance level (e.g. speech Acts and Pragmatic acts, lexicalization or grammaticalization of concepts, thematic role assignment, direct and indirect speech acts, etc) which can be discussed in unearthing meaning and meaning relations in communication. However, understanding and explaining meaning at sentence or utterance level often transcends the level of semantics and is best captured within the scope of pragmatics. While semantics deals with 'what does X mean'? Pragmatics deals with 'what did you mean by X'?

\section{Pragmatic Content}

Pragmatics as a linguistic field of study, is hinged on the premise of speech Acts Theory, - that language is used to say and do things - 'Locutionary Act' and 'Illocutionary Act'; that there is always some intended speaker meaning which could be rightly or wrongly understood /received by the listener(s)- 'Perlocutionary Act'; that there are some shared background knowledge between speaker and hearer/listener (context), aided by cooperative principle of speaking with the maxims of Quantity (give the right amount of information), Quality (try and make your contribution as true as possible) Relation (be relevant) and Manner (be perspicuous) Atolagbe (2010:58-60). Moreover, a number of maxims, such as the Tact Maxim, Politeness maxim, Generosity, Modesty, Agreement, Sympathy, Approbation Maxims (Levinson 1980, 1983; Leech, 1983) all contribute to our understanding and explications of how communication goes on smoothly (or otherwise).

\section{Cognitive Context}

We consider here, what is known of the speaker - Donald Trump, and how this reflects in his speech and relationships with his people the Americans, and the rest of the world.

Trump is the typical white American who is proud of his historical antecedents and records. A successful septogenarian businessman, he strongly believes in American values of democracy, freedom, human rights, capitalism, christian principles and self-pride or self worth, that the American is first among equals all over the world, and particularly that the American President has oversight functions over the entire world. He also believes that people from other undemocratic societies rush to America because of these long standing values that obtain in America. Whether he as a person has imbibed or practices these values is another issue entirely. For instance, opposing the popular Obama health scheme in his campaign speeches, belittling or deriding women (seeing them as sex toys), discriminating against blacks in his business concerns at a younger age in life, pushing against immigrants and refugees entering the U.S., etc may put a question mark on his true American democratic, liberal or Christian values. Must we consider what he says against what he does and who he is (or is supposed to be)?

\section{Social Context}

We consider here, the identity of the speaker (social and cultural), the social context of his speech and how these reflect in or affect his speech and his relationships with his American people, the growing immigrant population and the rest of the world. As discussed in Ogunba (2000) and Ogunsanwo in Ogunba (2000), many nations believe they have a lot to learn from America in terms of good governance, democracy and civil society; about separation and devolution of powers in a democracy, empowerment of citizens and strengthening political and economic institutions, as well as civic education and diplomacy in international relations. Many Americans are also aware of these facts and are proud to be Americans. 
However, Donald Trump, who had never held any political office, came on the political scene because he believed that the strength and power of America as the world's number one world power (probably being contested by Russia and China) was fast waning. The globalised world was also gradually taking 'their' America from them in many respects, all in the name of freedom and democracy. There was therefore a need to "reclaim" America for the American people. Hence, he came up with the slogan "America First". This slogan gave impetus to his subsequent saying, doing and being - even when he had to act on 'claims' or 'facts' which could not be substantiated and which one of his aids, Kellyanne Conway, decided to call 'Alternative facts'.

Such 'claims' or 'facts' form the basis for his national and international policies and relations that the world has seen him begin to implement as President of the United States of America. Indeed such pronouncement on building a wall between America and Mexico, to prevent illegal immigrants, on banning immigrants from seven predominantly Muslim countries from America and withdrawing visas from different categories of persons already issued with U.S. visas, relocating the capital of America in Israel to Jerusalem and supporting Israel against Palestine, re-evaluating America's foreign policies and relations with China, Russia, Brexit, etc, especially with regard to economic policies - are indeed reshaping discourses in America and across the world. These discourses are resonating with strong emotional backlashes - protests internally, protests in Britain, stranded immigrants at airports at the instance of implementation of the visa ban, face off between the Mexican and American Presidents, fluctuating stock trading results on Wall Street, etc.

\section{Big D Analysis}

Let us now consider speaking excerpts from the speech, specific actions of Trump and his person. Thereafter, we shall discuss the various implications of these discourse texts.

From the discussion of the semantic and pragmatic contents of the speech, we realize the identity of the new American President as one who is conservatively American, one who thinks so highly of his country and his people that he would not allow 'the people of the world' dictate to them, influence them negatively (as far as American values are concerned) nor infringe on their rights, wealth or wellbeing despite the democratic and civil nature of the American people and society. We see this speaker as someone who is not willing to toe the line of his more liberal predecessors; he talks tough just as he did throughout his campaigns - a position which apparently got him the votes of millions of native Americans, to the surprise of the entire world which had assumed that Hilary Clinton (the Democrat) would win as President.

It does not seem to matter though that this President based (and still bases) his claims/assertions on not just facts, but 'supposed facts' which could and can not be verified (e.g. that the elections were rigged in Hilary Clinton's favour, that the seven Muslim nations banned from America are terrorists, that the Mexicans and other immigrants are the major gangsters and criminals in America - which has led to the idea of 'alternative facts' as explained by his top aide Kellyanne Conway. The question to ask therefore is: Does Donald Trump reflect the true identity of the native American indeed? Despite protests against his actions, utterances, policies, etc which left many Americans embarrassed, emotional (positively or negatively), Trump still has great support among the local or indigenous Americans. His person, the conservative American identity is what we hear and see through what he says and does. What does this portend for America and the world? How do these alternative facts affect national and international discourses in and outside America? 


\section{National Implications}

The national implications of a Donald Trump President for America and American discourse include among others:

1. A divisive and emotionally unstable American society, which may affect families, states and the country negatively.

2. A test of the already established democratic institutions and democratic principles or practices which are dear to Americans and which hold them together as one, such as adjudication of the constitution by the legal or presidential arm of governance.

3. A re-examination of his own self and social identity by the President, in the light of reactions and counter reactions that arise from his sayings and actions; and also a reexamination of their selves and collective identity as Americans by many Americans in the light of the "America first" policy of the President.

4. Ultimately, a better, stronger, united America could emerge, or a weakened or destroyed America.

\section{International Implications}

As a consequence of the national implications as they may play out in the next four years of the Donald Trump administration, the following are the probable international implications:

1. Former allies of America may begin to re-consider their relations and ties with America (negatively or positively) especially in political and economic matters; this will particularly affect Israel, Britain and the European Union.

2. Former enemies of America may begin to strengthen their own capabilities and strengths with the possibility of challenging America as the number one world power, such as North Korea (which we have begun to see) Iran, Russia and maybe the Asian countries and China.

3. The developing nations may begin to exhibit a sense of hopelessness, with their citizens acting this out negatively since the "Big Brother Police Officer of the world, the Donor Agency to the poor and helpless" may no longer be forthcoming with economic and military assistance. As a result, such nations may also begin to strengthen ties with other world powers (China, Russia, Germany, France, Britain, etc.)

4. Religious individuals across the globe may become more adventurous or terroristinclined, with an influx into other nations, or perpetuate more dastardly terrorist acts against their perceived enemy- the United States of America, and its allies.

\section{Globalized Academic Implications}

Academics involved in language studies and communication studies, behavioural and social sciences, history and international relations, religion and peace studies, philosophy and every other aspect of human existence and welfare need to begin to pay attention to "discourses" in their respective domains which have some bearing on the implications highlighted thus far. This call arises from the fear of the power of language use and its immediate or far-reaching effects. Human character, society and institutions must be built and strengthened rather than destroyed. Individual societies and the world at large must remain a safe and peaceful place to live in. Academic pursuits, enterprise or endeavours must relate to the needs of the people and their society.

Hence, national and international discourses must be shaped and re-shaped in the light of what we know, what we hear, see or say, what we do and who we are, whether as leaders or ordinary citizens of our respective communities.

\section{CONCLUSION}

We have shown how the identity of the current President of America reflects in his speech and actions; we also pointed out the national and international implications of these 'acts'. Finally, 
we assert that what we know, say and do and who we are as leaders must enhance our society and its values, otherwise we have no business being at the helm of affairs in the first instance.

\section{References}

Adegbite, W. (2009) "Language, Gender and Politics: A General Perspective” In Odebunmi, A., Arua, E. A. and Arimi, S. (Eds.) Language, Gender and Politics: A Festschrift for Yisa Kehinde Yusuf. Lagos: Concept Publications pp. 9-22.

Adetunji, A. (2009): “Acts in the Inaugural Addresses of Nigeria's President Olusegun Obasanjo and America's President George Bush." Odebunmi, A. et. al. op. cit. 275-296.

Atolagbe, A. A. (2010) A Discourse Analysis of the Use of English in Politics: A Study of Aspects of Abacha's and Obasanjo's Speeches. An Unpublished Ph.D Thesis submitted to the University of Lagos.

Atolagbe, A. A. (2015) “"Saying and Unsaying” in the 2015 Nigeria Presidential Election Campaigns of Buhari and Jonathan.' Unpublished Paper Presentation at Obafemi Awolowo University, Faculty of Arts Humanities Conference; March, 2015.

Ayoola, K. A. (2007) 'An Anatomy of the Discourse Strategies Employed by Ken Saro-Wiwa, the Martyred Nigerian Environmental Rights Activist' Journal of the Nigeria English Studies Associations (JNESA). 3:1. pp. 48-57.

Beard, (2000): The Language of Politics London: Routledge.

Brown, G. and Yule, G. (1983): Discourse Analysis. Cambridge: University Press.

Chilton, P. and Schaffner, C. S. (1997). "Discourse and Politics" in Discourse and Social Interaction. Van Dijk, T. A. (ed.) London: Sage Publications. pp. 206-230.

Fairclough, N. (1989): Language and Power. Lagos and New York: Longman.

Fasold, (1990). Socio-linguistics of Language. Oxford: Blackwell.

Gee, J. P. (2014). An Introduction to Discourse Analysis: Theory and Method. New York: Routledge. $4^{\text {th }}$ Edition.

Hahn, D. F. (1989): “Political Language: the Art of Saying Nothing” in Lutz, W. (ed.) Illinois: National Council of Teachers of English.

Harris, Z. (1951): “Discourse Analysis”. Language. 28. pp. 1-30.

Leech, J. N. (1983): Principles of Pragmatics. London: Longman

Levinson, S. C. (1980): "Speech Act Theory: the State of the Art". Language and Linguistics Abstracts. $13(\mathrm{i}) .5$ - 24.

Mey, J. L. (1993) Pragmatics. Oxford: Blackwell.

Mey, J. L. (2001): Pragmatics. 2nd edition. Oxford, England: Blackwell

Ogunba, O. (2000) (ed.) Ibid.

Ogunsanwo, A. (2000) 'Good Governance, Democracy and Civil Society' In Ogunba, O. (ed.) The Empowerment of the Civil Society in a Democracy: Nigeria and the United States of America. Ile-Ife, Anchor Print Ltd.: American Studies Association of Nigeria.

Olateju, (1998): Discourse Analysis: Analyzing Discourse in the ESL Classroom. Nigeria: Crossland Educational Services.

Schiffrin, D. (1994): Approaches to Discourse. Oxford: Blackwell Publishers.

Sokari, S. and Ugwu, E. N. (2013) “ Metaphor as Pragmatic Act” A Pragmatic Analysis of the Reporting of Selected Discourses on the Niger Delta Crisis of Nigeria.", JNESA, Vol. 16, Nos 1\&2

Stubbs, M. (1983): Discourse Analysis: Text and Talk. Georgetown University. 